\title{
Performance Assessment of Left Main Canal of Bhimsagar Medium Irrigation Project Using Water Delivery and Technical Indicators
}

\author{
P. R. Patil*, Mahesh Kothari, P. K. Singh and S. R. Bhakar \\ Department of Soil and Water Engineering, CTAE, MPUAT, Udaipur, Rajasthan, India \\ *Corresponding author
}

\section{Keywords}

Adequacy; equity; dependability; water conveyance efficiency; on-farm application efficiency

\section{Article Info}

Accepted:

14 May 2020

Available Online:

10 June 2020

\begin{abstract}
A B S T R A C T
This study aimed to evaluate the left main canal (LMC) of the Bhimsagar medium irrigation project, Jhalawar using adequacy, dependability and equity, and water conveyance and on-farm application efficiency. These indicators calculated for each outlet of selected minors (three minor located at the head, middle and tail section) of LMC during 2016-2017 of rabi season. The ratio of water delivered (measured discharge at each outlet) and irrigation demand (calculated crop water requirement using CROPWAT 8.0 model) for major rabi crops (wheat, mustard, garlic and coriander) grown in the command area. The overall water conveyance efficiency of LMC was found as $77.95 \%$, whereas, for Kherli, Bagher and Badankheri minor of LMC observed as 74.94, 73.55 and $65.89 \%$, respectively. The on-farm application efficiency found at $76.89 \%$ in the command area of LMC. The results had shown fair (0.88 to 0.83$)$, fair $(0.84$ to 0.82$)$ and poor $(0.85$ to 0.28$)$ gate adequacy indicator (GAI) at head, middle and tail section of the LMC, respectively. All outlets of LMC had shown very 'poor' dependability with values ranging from 0.33 to $0.62(>0.25)$. Also, there is 'poor' equity $\left(\mathrm{CV}_{\mathrm{R}}\right)$ was found for selected minors of LMC as it values varied from 0.01 to $0.44(>0.25)$.
\end{abstract}

\section{Introduction}

Performance measures should be functions of state variables that have a direct impact on the fulfillment of system objectives, should be intuitively easy to interpret, and should be relatively easy to measure or predict (Molden and Gates, 1990). Most studies on irrigation system performance evaluation carried out in the past few years have been concerned with establishing performance criteria determining techniques for use in the analysis of parameters, or selecting common, comparable indicators (Small and Svendsen 1990; Rao 1993; Bos et al., 1994; Murray-Rust and Snellen 1993; Clemmens and Bos 1990). Water delivery, which is not adequate, equitable, dependable and efficient, can have an adverse effect on crop productivity (Marikar et al., 1992).

India shows a high degree of spatial and temporal variation of rainfall. Therefore, irrigation development is one way to deal with this variability in rainfall. Since independent, India has done remarkable work 
to improve and strengthen its irrigation sector. A number of irrigation scheme have been proposed to meet irrigation requirements in arid and semi-arid regions of the country. Huge investment has been made in infrastructure for irrigation schemes over the last half-century. But there is a perception that many irrigation schemes do not perform up to expectations or achieve their goals (Gorantiwar and Smout, 2005).

Rajasthan is the largest state of India covers nearly 10.4 per cent of the total geographical area (329 Million hectares) of the country.Out of which, two-third is under Desert, and only one third is available for agriculture use but has only 1.04 percent for water resources (Rajput et al., 2017). The canal water is one of the primary sources of irrigation in the arid and semiarid regions. The irrigation scenario in India characterized by poor irrigation system performance, increased demand for higher productivity and increased soil salinity. Proper irrigation management should provide higher economic output besides water saving and high yield (Pareira, 2003).

Performance evaluations of irrigation schemes identify and examine deficiencies in system design, planning, operation, management and maintenance (Sharma et al., 2018). Many researchers have proposed indicators and a framework for evaluation (Bos et al., 2005; Gorantiwar and Smout, 2005). According to Clemmens and Molden (2007), earlier there have been two major approaches to evaluate the overall performance of irrigation systems: its gross production or return on investment and its efficiency of water use.

The aimed of this study was to assess the performance of left main canal of Bhimsagar medium irrigation project, Jhalawar using water delivery and technical indicators through measure variables on site.

\section{Description of the study area}

\section{Bhimsagar medium irrigation project (BMIP)}

Bhimsagar dam is located at Mau-Borda, TalAsnawar, about $2 \mathrm{~km}$ in the south, Jhalawar district, Rajasthan. The dam is lies between longitude $76^{\circ} 21^{\prime}$ and latitudes $24^{\circ} 33$ at 312 meters above MSL. Whereas, Bhimsagar command area lies between longitudes $76^{\circ} 15^{\prime}$ to $76^{\circ} 21^{\prime} \mathrm{N}$ and latitudes $24^{\circ} 33^{\prime}$ to $24^{\circ} 49^{\prime} \mathrm{E}$. The dam is $37.50 \mathrm{~m}$ high and 161.58 long straight non-overflow masonry wall constructed across Ujjar river, a tributary of Kalisindh river. The location of the study area illustrated in Figure 1. The main purpose of this dam construction was to provide irrigation facilities to the Bhimsagar command area. The gross command area (GCA) of Bhimsagar medium irrigation project is 10512 ha, while the culturable command area (CCA) is 9984 ha. It has a Left Main Canal (LMC) and Right Main Canal (RMC) of length $29.26 \mathrm{~km}$ and $16.36 \mathrm{~km}$ respectively for irrigating command of 7278 ha and 2708 ha respectively.

The present study carried out to evaluate the water delivery performance of LMC.The area receives an average annual rainfall of $943 \mathrm{~mm}$. The maximum temperature ranges in the summer are $43-48^{\circ} \mathrm{C}$ and minimum as 1$2.6^{\circ} \mathrm{C}$. The soil in the command area is black cotton with morinda mixed, is suitable for the cultivation of all crops: the crops soybean, maize, black gram, small cereals are grown majorly in Kharif. The moong and fodder crops are grown in summer, where irrigation water is available. Whereas, in rabi season wheat, mustard, garlic and coriander crops are grown majorly in the command area. Field data regarding the existing cropping pattern iscollected from Khanpur tehsil office, Jhalawar, Rajasthan (India). The evaluation has done for LMC and its three selected 
minor, these minors located at head, middle and tail section namely Kherli, Bagher and Badankheri. Total 9, 6 and 5 outlets taken for evaluation purpose of selected minors, respectively. The water is diverted from the canal to minors by head regulator. The supply of irrigation water is measured using parshall flume situated at field outlet.

\section{Materials and Methods}

\section{Determination of water conveyance and on-farm application efficiencies}

Water conveyance efficiency $\left(\mathrm{E}_{\mathrm{C}}\right)$ was calculated for the right main canal at head, middle and tail section of the study area as the ratio of the inflow-outflow (volume of water delivered to the volume of water placed in the canal) method, as a percentage. Evaporation losses were ignored.

The conveyance efficiency mainly depends on the length of the canals, the soil type or permeability of the canal bank and the condition of the canals. While, on transit through canals losses like, evaporation, deep percolation, seepage, overtopping, rat holes in the canal etc. eventually happen (CWC, 2014).

So, it was necessary to assess the losses to determine the quantity of water actually delivered at the plant in the project area. Conveyance loss per $\mathrm{km}$ factor was evaluated in three reaches of each canal and their selected minors by inflow and outflow method.

The inflow/outflow at head, middle and tail of the canals and minors calculated by an areavelocity method. Whereas, velocity was measured by float method with taking $200 \mathrm{~m}$ reach at head, middle and tail. Further, the conveyance efficiency of the canal was computed by the following equation-
$E_{C}=\frac{\text { Total water delivery at inletto the block of field }}{\text { Water released at the project head work }} \times 100$

\section{On-farm application efficiency $\left(E_{\mathbf{a}}\right)$}

The ASCE (1978) 'on-farm' efficiency definitions use depths of application. It was worked out by the ratio of the crop water requirement as per Modified Penman method for major crops grown in rabi season for which the project has provided irrigation to the quantum of water which is made available to crops from the field outlets of the canal system (CWC, 2014), the formula is given below to calculate the field application efficiency.

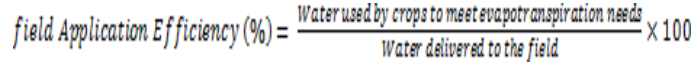

The amount of water required for irrigation calculated by taking the soil samples at several places in the field before and after irrigation and estimated the moisture deficiency or the depth of water required to bring the soil in the root zone to field capacity.

The water applications are then figured out on the basis of prevalent application efficiency. The following equation gives the depth of water available in soil depth i.e. $\mathrm{cm}$. of water per $\mathrm{cm}$. of water per meter of soil:

$$
D=\frac{\omega \times \gamma_{S} \times d}{100}
$$

Where,

$\mathrm{D}=\quad \mathrm{cm}$ of water in soil depth $(\mathrm{d})$

$\omega=$ moisture content of soil in $\%$

by weight

$\gamma_{s} \quad=\quad$ bulk density of soil

Weight of oven dry soil in gms

field volume of sample in cum

$\mathrm{d}=$ depth of soil in $\mathrm{cm}$. 
Measurement of the water delivered to minors and their outlets

The amount of water delivered to minors and outlets are measured using storage gauge painted on minor sections and depth measured at the field outlet using parshall flume (3-inch size),respectively. It was also taken care of collection of the readings whenever little changes in flow depth at each canal section during entire irrigation season (November to March). In present study, irrigation supply for the April month was ignored for calculation due to canal run upto month ofMarch only.Further, the values of water delivered $\left(\mathrm{Q}_{\mathrm{D}}\right)$ and water required $\left(\mathrm{Q}_{\mathrm{R}}\right)$ were used to calculate adequacy, dependability, and equity of selected minors and outlets of LMC.

\section{Determination of crop water requirement (CWR)}

To calculate irrigation requirements, inputs to the software CROPWAT 8.0 windows (Julaila, 2009) are crop data (length of initial, development, mid-season and late-season stages and crop-coefficient values of these four stages) and planting date. The climatic data were collected from Irrigation Department, Government of Rajasthan, Jhalawar, for the duration of 2016 to 2017. Average reference evapotranspiration $\left(\mathrm{ET}_{0}\right)$ calculated on a daily basis recommended penman-Monteith method (Allen et al., 1989).The crop coefficient $\left(K_{c}\right)$ for initial, development, mid-season and late-season growth stage of referenced crops were taken from (FAO-56, 1998). Actual crop evapotranspiration (crop water consumption) $\mathrm{ET}_{\mathrm{C}}$ values were obtained by correcting $\mathrm{ET}_{0}$ values with the $\mathrm{K}_{\mathrm{c}}$. The output of the software provided irrigation requirement in $\mathrm{mm} / \mathrm{dec}$ (mm per 10 days) during the crop period. Net water requirement for each outlet $\left(\mathrm{Q}_{\mathrm{R}}\right)$ was calculated using crop water demand $(\mathrm{cm})$, irrigated area (ha) and on-farm application efficiency (per cent). The crop-wise water requirement for rabi crops were calculated, is presented in Table 1.

\section{Determination of performance indicators}

\section{Water delivery performance indicators}

Water delivery performance at selected minor of right main canal was determined according to the indicators of adequacy, dependability and equity as proposed by Molden and Gates (1990) and subsequently applied by Unal et al., (2004); Vandersypen et al., (2005); Dhole and Kothari, (2011); Rajput et al., (2017); Sharma et al., (2018); and Tarate and Awari (2018).

\section{Adequacy $\left(\mathbf{P}_{\mathrm{A}}\right)$}

Adequacy of delivery is dependent on water supply, specified delivery schedules, the capacity of hydraulic structures to delivery water according to the schedules, and the operation and maintenance (O\&M) (Molden and Gates, 1990).

The adequacy can be estimated for an irrigation system as a whole, or subsystems and sub-command areas. Locally, for an offtake, the adequacy is simply the ratio of actual to required delivery. The adequacy can be computed by given below equation:

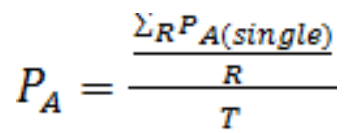

Where,

$$
P_{A}=\frac{Q_{D}}{Q_{R}} \text {, if } Q_{D} \leq Q_{R}, P_{A}=1 \text {, otherwise }
$$

The term $Q_{D}$ and $Q_{R}$ are called the amount of water delivered and required

$P_{A(\text { single })}=$ the performance measure relatively to adequacy at the secondary canal and a month; 
$R=$ Region served by the system (secondary canals for this study)

$T \quad=$ Time period (rabi Season)

Note that the adequacy value becomes 1.0 if the delivered discharge is higher than the targeted or required discharge showing that this indicator will not penalize the water user for receiving more water than intended. Nevertheless, this may also create an environmental problem and efficiency problem if the water supply is too much as the indicator does not indicate what is the magnitude of water that above the targeted supply.

\section{Dependability $\left(\mathbf{P}_{\mathbf{D}}\right)$}

Dependability is defined as temporal uniformity of the ratio of the delivered amount of water to the required or scheduled amount. A system that dependably delivers an inadequate amount of water may be more desirable than one that delivers on the average an adequate or unpredictable supply. A farmer can plan for dependable delivery of an inadequate supply of water by planting less or growing different crops or adjusting other farming inputs. However, a farmer cannot easily plan when the supply of water is unpredictable (Molden and Gates, 1990). The uncertainty and undependability in the delivery may cause confusion and conflict among the farmers.

The degree of temporal variability is thein other words dependability may be measured through given below equation:

$P_{D}=\frac{\sum_{R} C V_{T}\left(\frac{Q_{D}}{Q_{R}}\right)}{R}$

Where,

$P_{D} \quad=$ Performance measure relative to dependability or reliability;
$C V_{T}\left(\frac{Q_{D}}{Q_{R}}\right)=$ Temporal coefficient of variation of the ratio of $Q_{D}$ to $Q_{R}$ over period " $T$ "

The value of indicator $\mathrm{P}_{\mathrm{D}}$ can qualify the degree of temporal variability. The closer the value of this indicator is to zero, the more reliable the relative supply of canal water becomes over time.

\section{Equity $\left(\mathbf{P}_{\mathbf{E}}\right)$}

Equity, as related to water-delivery systems, can be defined as the delivery of a fair share of water to users throughout the system. A share of water represents a right to use specified amount. The fair share of water may be based on a legal right for water, as in a prior appropriation system, or set as a fixed proportion of a water supply, as is done in many rotational delivery schemes. However, it is essential to define measures relating to equity so that systems can be designed or rehabilitated to deliver water impartially to users served by the system.

Several alternative definitions of waterdelivery, equity has been suggested. However, in the present study, equity is defined as being spatial uniformity of the ratio of the delivered amount of water to the required or scheduled amount (Molden and Gates, 1990; Fan et al., 2018).

$P_{E}=\frac{\sum_{T} C V_{R}\left(\frac{Q_{D}}{Q_{R}}\right)}{T}$

Where,

$P_{E} \quad=$ The performance measure relative to equity;

$C V_{R}\left(\frac{Q_{D}}{Q_{R}}\right)=$ Spatial coefficient of variation (ratio of standard deviation of mean) of the ratio $Q_{D}$ to $Q_{R}$ (relative water delivery) at delivery points over the hydraulic level or 
reaches $R$. as the value of $P_{E}$ is close to zero, the degree of equity in water delivery would be higher. In general, $\mathrm{P}_{\mathrm{A}}, \mathrm{P}_{\mathrm{D}}$ and $\mathrm{P}_{\mathrm{E}}$ represent the relationship between the actual water supply and crop water requirement as the comprehensive reflection of performance in the irrigation scheme. The evaluation standard for performance indicators was formed by Molden and Gates, 1990 as shown in Table 2.

\section{Results and Discussion}

\section{Existing cropping pattern}

Cropping pattern in the command area of LMC was observed as 1463.71, 217.34 and 221.86 ha area grown under major crops (wheat, mustard, garlic and coriander) at head (Kherli), middle (Bagher) and tail (Badankheri) section of LMC.

\section{Water conveyance efficiency $\left(\mathbf{E}_{\mathrm{c}}\right)$}

As given in Table 3, the water conveyance efficiency of LMC was measured at three locations selected at head, middle and tail sections which is observed as 90.25, 81.25 and 62.35 per cent respectively. Whereas, an average conveyance efficiency observed as 77.95 per cent which is within acceptable range for a distribution system. The average conveyance efficiency was found as 74.94, 73.55 and 65.89 per cent for selected minor's i.e. Kherli, Bagher and Badankheriat their head, middle and tail section respectively, it is depicted in Figure 2. Further, it was observed during fieldwork that water was leaking at places where the canal was breached, infested with vegetation, and also water overtops the canal banks at some places. This is one of the major reason for poor water delivery to tail reaches. Lesser the conveyance efficiency higher is the conveyance loss that creates problem for farmers having fields at lower sections of canal command area. Hamdy, 2007 reported that very often the conveyance losses of conduits (unlined canals or leak pipes) are much too large, a $30 \%$ loss percentage of the available water is common in irrigation systems.

\section{On-farm application efficiency $\left(\mathrm{E}_{\mathrm{a}}\right)$}

For calculating on-farm application efficiency, 1463 ha area has been taken which is $20.10 \%$ of the LMC command area. The discharge measured at Kherli minor was observed as 1.05 cum ec. The bulk density was found as $1.2 \mathrm{~g} / \mathrm{cc}$ and depth of water used for the irrigation was found $10.30 \mathrm{~cm}$. Whereas, an average application efficiency was found 73.56 per cent which is taken for the further calculation of on farm application efficiency. The detail calculation of on-farm application efficiency is given in Table 4. The time was taken as 21 days (1814400 sec) for the irrigation. Further, field irrigation requirement (FIR) was calculated dividing net irrigation requirement (NIR) by application efficiency which resulted as $315.54 \mathrm{~mm}$. Therefore, the on-farm application efficiency was the calculated dividing FIR (0.81) by actual supply (1.05 cum ec) which resulted as 76.98 per cent, is presented in Table 4. According to Gurgor et al., 1996, water application efficiency in a well-planned irrigation system would be expected to be not less than 50-60\%. Therefore, as looking to observed figures, water application efficiency values in the study area can be found to be at or above the acceptable limit

Ratio of water delivered $\left(Q_{D}\right)$ and irrigation water required $\left(Q_{R}\right)$ for selected minors and outlets of LMC

From Figure 3, it can be observed that $Q_{D}$ values for the head and middle section were greater than $\mathrm{Q}_{\mathrm{R}}$ values during November March, whereas, at $Q_{R}$ values for tail section at the last three outlets observed greater than $\mathrm{Q}_{\mathrm{D}}$ values, according to Kazbekov et al., 
(2009), is water delivered in a surplus amount rather than required and should be considered as a non-beneficial use of the resource. It is the reason due to water conveyance efficiency at tail section observed very low, which unable to provide adequate supply to outlets. Where water delivered at head and middle section of the canal was observed more, because canal runs full supply depth compared to tail section reach. Korkmaz et al., (2009) was also reported that, it was generally true that $\mathrm{Q}_{D}$ values were higher than $Q_{R}$ values outside the time when the dam was not being operated, and when the dam was in operation the opposite was true. This indicates that when the dam is in operation, the selected tertiaries were not met their irrigation water requirements.

\section{Water delivery performance indicators}

\section{Adequacy $\left(\mathbf{P}_{\mathrm{A}}\right)$}

The ratio of $Q_{D}$ and $Q_{R}$ i.e. gate adequacy indicators (GAI) for each outlet for the year 2016-17 (November to March) for LMC, is given in Table 5. Temporal average value GAI for LMC outlets ranges from 0.88 to 0.83 at head, 0.84 to 0.82 at middle and 0.85 to 0.28 at tail section, is illustrated in Figure 4. The values were observed highest in the month of November, December and January showing 'good' adequacy, 'fair' in month of February, whereas, 'poor' in March. Almost maximum outlets providing 'fair' water delivery to the fields except outlets at tail section of each minor found as 'poor' water delivery points on the LMC. Therefore, there is an urgent need to restore the damages, vegetation infestation and silt deposition from these outlet channels. An average of both spatial and temporal adequacy indicator was obtained as 0.77 showing 'poor' of water delivery system for LMC. The spatial average of gate adequacy indicator (GAI) at head and middle section was found as 0.82 and 0.81 indicating 'fair' adequacy, respectively.
While, the value 0.71 implying 'poor' adequacy at tail section of LMC, is graphically presented in Figure 5.

\section{Dependability $\left(\mathbf{P}_{\mathbf{D}}\right)$}

The dependability is evaluated by the values of $\mathrm{CV}_{\mathrm{T}}$ (temporal coefficient variation). The values of $\mathrm{CV}_{\mathrm{T}}$ for $\mathrm{LMC}$ are given in Table 6 and depicted in Figure 6. All outlets of LMC had shown 'poor' dependability with values ranging from 33.90 to $62.46 \%$. The temporal values of $\mathrm{CV}_{\mathrm{T}}$ inferred that the canal water supply at each selected outlets is inadequate to supply irrigation water with respective to time. In the month of March, supply of water getting 'fair' in condition. It can be concluded that due to water takes much time at head and middle section at early months such as from November to February, once the canal bed gets saturated, water flowing faster rate in month of March.

\section{Equity $\left(\mathbf{P}_{\mathbf{E}}\right)$}

The Equity is evaluated by the values of $\mathrm{CV}_{R}$ (spatial coefficient variation). Table 7 describes the $C V_{R}$ values calculated for selected outlets of minors located at head, middle and tail section of LMC. It can be observed that the $C V_{R}$ values at all selected outlets of LMC as 'poor' equity in delivered and required volume water. An average ratio of $\mathrm{Q}_{\mathrm{D}}$ and $\mathrm{Q}_{\mathrm{R}}$ ranges from 1.00 to $0.28,1.00$ to 0.18 , and 1.00 to 0.11 at head, middle and tail sections of LMC respectively during month of November to March. The $C_{R}$ values observed as zero, indicates that "good" equitable distribution of canal discharge, whereas, it slightly increased in the month of January, February and March at all three sections of LMC, is illustrated in Figure 8. The analysis revealed that, the discharge has gone inequity from January to March due to increase water demand in command area. Also, conveyance efficiency of all sections of the canal has affect their discharge 
distribution. Some of researchers are reported such as Sharma et al., (2018) also reported for SomKamlaAmba Irrigation scheme overall average adequacy was found to be poor. Fair dependability in the performance of the system was observed. Equity values were found to be very low, confirming the failure of system management in water distribution. Unal et al., (2004) found the irrigation water delivery indicators of adequacy, dependability and equity of the Menemen Left Bank system to be poor, while efficiency was fair. Menemen Left Bank system to be poor, while efficiency was fair. Molden and Gates (1990) found adequacy and efficiency to be fair, and dependability poor in Kaudilla irrigation system in Sri Lanka; in the Minneriya irrigation system these indicators were respectively poor, fair and poor.

Table.1 Crop wise water requirement of rabi crops (mm)

\begin{tabular}{|c|c|c|c|c|}
\hline \multirow{2}{*}{ Month/Crop } & \multicolumn{4}{|c|}{ Net Irrigation Requirement (mm) } \\
\cline { 2 - 5 } & Wheat & Mustard & Garlic & Coriander \\
\hline Nov & 17.2 & 22.7 & 22.8 & 16.7 \\
\hline Dec & 34.6 & 47.8 & 68.1 & 42.9 \\
\hline Jan & 64.6 & 79.0 & 75.6 & 82.8 \\
\hline Feb & 98.2 & 109.9 & 87.8 & 98.8 \\
\hline Mar & 95.4 & 67.1 & 134.5 & - \\
\hline Total (mm) & 310.0 & 326.5 & 388.8 & 241.2 \\
\hline
\end{tabular}

Table.2 Evaluation Standard for Water Delivery Performance Indicators

\begin{tabular}{|c|c|c|c|}
\hline \multirow{2}{*}{ Measure } & \multicolumn{3}{|c|}{ Performance Classes } \\
\cline { 2 - 4 } & Good & Fair & Poor \\
\hline $\boldsymbol{P}_{\boldsymbol{A}}$ & $0.90 \leq P_{A} \leq 1.00$ & $0.80 \leq P_{A} \leq 0.90$ & $P_{A}<0.80$ \\
\hline $\boldsymbol{P}_{\boldsymbol{D}}$ & $0.0 \leq P_{D} \leq 0.10$ & $0.10 \leq P_{D} \leq 0.25$ & $P_{D}>0.25$ \\
\hline $\boldsymbol{P}_{\boldsymbol{E}}$ & $0.0 \leq P_{E} \leq 0.10$ & $0.10 \leq P_{E} \leq 0.20$ & $P_{E}>0.20$ \\
\hline
\end{tabular}

Water conveyance efficiency was found to be 'fair' at the required level for the trapezoidal channel, partially lined canal. The most important factor which reduce efficiencies was damages associated with canal deformation, unauthorized outlets, and vegetation infestation. On-farm application efficiency was also found to be fair for the LMC.

Water delivery performance indicator such as adequacy was found from fair to poor sectionwise as well as month wise. Whereas, dependability, and equity found to be poor respectively for selected minors of LMC. These indicators shown that LMC irrigation system was inadequate to supply required water, water use efficiency is relatively high, unable to supply irrigation water at right time and inequitable share of irrigation water from the canal.

As results, water delivery system was found not good in condition as well as unable supply required amount of irrigation water to tail-end users. 
Table.3 Computation of Conveyance Efficiency of the LeftMain Canal System and its Selected Minor

\begin{tabular}{|c|c|c|c|c|c|c|c|c|c|c|}
\hline $\begin{array}{l}\text { S. } \\
\text { No. }\end{array}$ & & & $\begin{array}{r}\text { Total } \\
\text { length } \\
(\mathbf{K m})\end{array}$ & Location & $\begin{array}{c}\text { Effective } \\
\text { Length Km }\end{array}$ & $\begin{array}{l}\text { Inflow } \\
\text { (cumec) }\end{array}$ & $\begin{array}{l}\text { Outflow } \\
\text { (cumec) }\end{array}$ & $\begin{array}{c}\text { Conveyance loss } \\
\text { per } \mathbf{k m}(\%)\end{array}$ & $\begin{array}{c}\text { Conveyance } \\
\text { efficiency }(\%)\end{array}$ & $\begin{array}{c}\text { Average Conveyance } \\
\text { efficiency }(\%)\end{array}$ \\
\hline \multirow[t]{3}{*}{1} & \multirow[t]{3}{*}{ Main canal } & \multirow[t]{3}{*}{ LMC } & \multirow[t]{3}{*}{29.26} & Head & $0-9.7$ & \multirow[t]{3}{*}{5.19} & 5.089 & 9.75 & 90.25 & \multirow[t]{3}{*}{77.95} \\
\hline & & & & Middle & $9.7-19.4$ & & 4.995 & 18.75 & 81.25 & \\
\hline & & & & Tail & $19.4-29.26$ & & 4.799 & 37.65 & 62.35 & \\
\hline \multirow[t]{3}{*}{ I } & \multirow[t]{9}{*}{ Minor's } & \multirow{3}{*}{$\begin{array}{l}\text { Kherli } \\
\text { (Head) }\end{array}$} & \multirow[t]{3}{*}{7.80} & Head & $0-2.6$ & \multirow[t]{3}{*}{1.05} & 1.022 & 13.56 & 86.44 & \multirow[t]{3}{*}{74.87} \\
\hline & & & & Middle & 2.6-3.9 & & 1.001 & 23.48 & 76.52 & \\
\hline & & & & Tail & $3.9-7.8$ & & 0.970 & 38.14 & 61.86 & \\
\hline \multirow[t]{3}{*}{ II } & & \multirow{3}{*}{$\begin{array}{l}\text { Bagher } \\
\text { (Middle) }\end{array}$} & \multirow[t]{3}{*}{1.77} & Head & $0-0.56$ & \multirow[t]{3}{*}{0.12} & 0.116 & 17.44 & 82.56 & \multirow[t]{3}{*}{77.40} \\
\hline & & & & Middle & $0.56-0.85$ & & 0.114 & 24.75 & 75.25 & \\
\hline & & & & Tail & $0.85-1.77$ & & 0.111 & 37.16 & 62.84 & \\
\hline \multirow[t]{3}{*}{ III } & & \multirow{3}{*}{$\begin{array}{l}\text { Badankheri } \\
\quad \text { (tail) }\end{array}$} & \multirow[t]{3}{*}{1.77} & Head & $0-0.56$ & \multirow[t]{3}{*}{0.27} & 0.257 & 24.11 & 75.89 & \multirow[t]{3}{*}{71.94} \\
\hline & & & & Middle & $0.56-0.85$ & & 0.252 & 32.48 & 67.52 & \\
\hline & & & & Tail & $0.85-1.77$ & & 0.270 & 45.75 & 54.25 & \\
\hline
\end{tabular}

Table.4 Calculation of on-farm application efficiency for LMC

\begin{tabular}{|c|c|c|c|c|c|c|c|c|c|c|c|c|c|c|c|}
\hline $\begin{array}{l}\text { S. } \\
\text { No. }\end{array}$ & $\begin{array}{c}\text { Rabi } \\
\text { Crops }\end{array}$ & $\begin{array}{l}\text { Crop } \\
\text { period } \\
\text { (days) }\end{array}$ & $\begin{array}{c}\text { Area } \\
\text { covered } \\
\mathbf{m}^{2}\end{array}$ & $\begin{array}{c}\text { Time } \\
\text { elapsed } \\
\text { sec }\end{array}$ & $\begin{array}{r}\mathbf{E T}_{\mathbf{O}} \\
(\mathbf{m m})\end{array}$ & $\mathbf{K}_{\mathbf{c}}$ & $\begin{array}{c}\mathbf{E T}_{\mathrm{c}} \\
(\mathbf{m m}) \\
(4 * 5)\end{array}$ & $\begin{array}{c}\mathbf{P} \\
(\mathbf{m m})\end{array}$ & $\begin{array}{c}\mathbf{R}_{\mathbf{e}} \\
(\mathbf{m m})\end{array}$ & $\begin{array}{c}\text { NIR = } \\
(6+7)= \\
8\end{array}$ & $\begin{array}{l}\text { Application } \\
\text { efficiency }\end{array}$ & $\begin{array}{c}\text { FIR } \\
(\mathbf{m m})\end{array}$ & $\begin{array}{l}\text { Total } \\
\text { FIR } \\
\left(\mathbf{m}^{3} / \mathbf{s}\right)\end{array}$ & $\begin{array}{l}\text { Actual } \\
\text { supply } \\
\text { (Cumec) }\end{array}$ & $\begin{array}{c}\text { On-farm } \\
\text { application } \\
\text { efficiency }(\%)\end{array}$ \\
\hline & & 1 & 2 & 3 & 4 & 5 & 6 & 7 & 8 & 9 & 10 & 11 & & 12 & \\
\hline 1 & Wheat & 120 & 8428108 & 1814400 & 60.06 & 1.15 & 69.07 & 0 & 0 & 69.07 & 0.74 & 93.34 & 0.43 & 1.05 & \\
\hline 2 & Garlic & 130 & 2283692 & 1814400 & 82.20 & 1.05 & 86.31 & 0 & 0 & 86.31 & 0.74 & 116.64 & 0.15 & & 76.98 \\
\hline 3 & Mustard & 110 & 3918200 & 1814400 & 66.77 & 1.17 & 78.12 & 0 & 0 & 78.12 & 0.74 & 105.57 & 0.23 & & \\
\hline \multicolumn{3}{|c|}{ Total } & 14630000 & & & & & & & & & 315.54 & 0.81 & 1.05 & \\
\hline
\end{tabular}

Calculation of Application efficiency

\begin{tabular}{|c|c|c|c|c|c|c|c|}
\hline $\begin{array}{c}\text { Area } \\
\left(\mathbf{m}^{2}\right)\end{array}$ & $\begin{array}{c}\text { Time } \\
\text { elapsed } \\
\text { (sec) }\end{array}$ & $\begin{array}{l}\text { Respective } \\
\text { discharge } \\
\text { (m3/sec) }\end{array}$ & $\begin{array}{l}\text { Area of fields } \\
\qquad\left(\mathbf{m}^{2}\right)\end{array}$ & $\begin{array}{c}\text { Total volume } \\
\qquad\left(\mathbf{m}^{\mathbf{3}}\right)\end{array}$ & $\begin{array}{c}\text { Depth } \\
\text { applied }(\mathbf{c m})\end{array}$ & $\begin{array}{c}\text { Depth water } \\
\text { used for the } \\
\text { irrigation }(\mathrm{cm})\end{array}$ & $\begin{array}{c}\text { Application } \\
\text { efficiency } \\
(\%)\end{array}$ \\
\hline 14630000 & 1814400 & 0.22 & 2850800 & 399168 & 14.00 & 10.30 & 73.56 \\
\hline
\end{tabular}


Calculation of depth of water used for the irrigation

\begin{tabular}{|c|c|c|c|c|c|}
\hline Farmer's & Time of & \multicolumn{4}{|c|}{ Soil moisture contents, \% of dry weight } \\
\hline Field & Sampling & \multicolumn{4}{|c|}{ Soil depths, cm } \\
\cline { 3 - 6 } & & $\mathbf{0 - 2 0}$ & $\mathbf{2 0 - 4 0}$ & $\mathbf{4 0 - 6 0}$ & $\mathbf{6 0 - 8 0}$ \\
\hline $\begin{array}{c}\text { Field } \\
\text { (Kherli } \\
\text { minor) }\end{array}$ & $\begin{array}{c}\text { Before } \\
\text { Irrigation }\end{array}$ & 8.50 & 9.50 & 8.85 & 7.35 \\
\cline { 2 - 6 } & $\begin{array}{c}\text { After } \\
\text { Irrigation }\end{array}$ & 18.57 & 19.83 & 21.20 & 17.50 \\
\hline
\end{tabular}

Table.5 Average Values of Gates Adequacy Indicator (GAI) for LMC

\begin{tabular}{|c|c|c|c|c|c|c|c|c|}
\hline \multirow{2}{*}{$\begin{array}{l}\text { Location of } \\
\text { Minor }\end{array}$} & \multirow{2}{*}{$\begin{array}{c}\text { Outlet } \\
\text { No. }\end{array}$} & \multicolumn{5}{|c|}{ Ratio of $Q_{D} / Q_{R}$} & \multirow[t]{2}{*}{ GAI } & \multirow[t]{2}{*}{ Average } \\
\hline & & NOV & DEC & JAN & FEB & MAR & & \\
\hline \multirow{9}{*}{$\begin{array}{l}\text { Kherli } \\
\text { (Head) }\end{array}$} & $1 \mathrm{~L}$ & 1.00 & 1.00 & 1.00 & 1.00 & 0.32 & 0.86 & \multirow[t]{9}{*}{0.86} \\
\hline & $2 \mathrm{R}$ & 1.00 & 1.00 & 1.00 & 1.00 & 0.26 & 0.85 & \\
\hline & $3 \mathrm{R}$ & 1.00 & 1.00 & 1.00 & 1.00 & 0.32 & 0.86 & \\
\hline & $4 \mathrm{~L}$ & 1.00 & 1.00 & 1.00 & 1.00 & 0.28 & 0.86 & \\
\hline & $5 \mathrm{~L}$ & 1.00 & 1.00 & 1.00 & 1.00 & 0.20 & 0.84 & \\
\hline & $6 \mathrm{R}$ & 1.00 & 1.00 & 1.00 & 1.00 & 0.17 & 0.83 & \\
\hline & $7 \mathrm{R}$ & 1.00 & 1.00 & 1.00 & 1.00 & 0.19 & 0.84 & \\
\hline & $8 \mathrm{R}$ & 1.00 & 1.00 & 1.00 & 1.00 & 0.39 & 0.88 & \\
\hline & 9L & 1.00 & 1.00 & 1.00 & 1.00 & 0.36 & 0.87 & \\
\hline \multirow{6}{*}{$\begin{array}{l}\text { Bagher } \\
\text { (Middle) }\end{array}$} & $10 \mathrm{R}$ & 1.00 & 1.00 & 1.00 & 0.97 & 0.15 & 0.82 & \multirow[t]{6}{*}{0.83} \\
\hline & $11 \mathrm{~L}$ & 1.00 & 1.00 & 1.00 & 1.00 & 0.18 & 0.84 & \\
\hline & $12 \mathrm{R}$ & 1.00 & 1.00 & 1.00 & 1.00 & 0.19 & 0.84 & \\
\hline & $13 \mathrm{~L}$ & 1.00 & 1.00 & 1.00 & 0.94 & 0.17 & 0.82 & \\
\hline & $14 R$ & 1.00 & 1.00 & 1.00 & 1.00 & 0.21 & 0.84 & \\
\hline & $15 \mathrm{R}$ & 1.00 & 1.00 & 1.00 & 0.97 & 0.15 & 0.82 & \\
\hline \multirow{7}{*}{$\begin{array}{c}\text { Badankheri } \\
\text { (Tail) }\end{array}$} & $16 \mathrm{~L}$ & 1.00 & 1.00 & 1.00 & 1.00 & 0.24 & 0.85 & \multirow[t]{6}{*}{0.62} \\
\hline & $17 R$ & 1.00 & 1.00 & 1.00 & 1.00 & 0.21 & 0.84 & \\
\hline & $18 \mathrm{~L}$ & 1.00 & 1.00 & 0.64 & 0.51 & 0.07 & 0.64 & \\
\hline & $19 R$ & 1.00 & 1.00 & 0.61 & 0.48 & 0.07 & 0.63 & \\
\hline & $20 \mathrm{~L}$ & 1.00 & 0.74 & 0.26 & 0.21 & 0.03 & 0.45 & \\
\hline & $21 \mathrm{~L}$ & 0.88 & 0.33 & 0.11 & 0.09 & 0.01 & 0.28 & \\
\hline & Average & 0.99 & 0.96 & 0.89 & 0.87 & 0.20 & 0.78 & 0.77 \\
\hline
\end{tabular}


Table.6 Dependability-Values of Temporal Coefficient of Variation $\left(\mathrm{CV}_{\mathrm{T}}\right)$ of the Ratio $\left(Q_{D} / Q_{R}\right)$ for $L M C$

\begin{tabular}{|c|c|c|c|c|c|c|c|c|c|c|}
\hline \multirow{2}{*}{$\begin{array}{c}\text { Location } \\
\text { of } \\
\text { Minor }\end{array}$} & \multirow{2}{*}{$\begin{array}{l}\text { Outlet } \\
\text { No. }\end{array}$} & \multicolumn{5}{|c|}{ Ratio of $Q_{D} / Q_{R}$} & \multirow[t]{2}{*}{ Avg. } & \multirow{2}{*}{$\begin{array}{l}\text { Std. } \\
\text { Dev. } \\
(\sigma)\end{array}$} & \multirow{2}{*}{$\begin{array}{l}\mathbf{C V}_{\mathrm{T}} \\
(\%)\end{array}$} & \multirow{2}{*}{$\begin{array}{c}\text { Avg. } \\
\text { of } \\
\mathrm{CV}_{\mathrm{T}}\end{array}$} \\
\hline & & NOV & DEC & JAN & FEB & MAR & & & & \\
\hline \multirow[t]{9}{*}{ Head } & $1 \mathrm{~L}$ & 1.00 & 1.00 & 1.00 & 1.00 & 0.32 & 0.86 & 0.27 & 31.48 & \multirow[t]{9}{*}{33.90} \\
\hline & $2 \mathrm{R}$ & 1.00 & 1.00 & 1.00 & 1.00 & 0.26 & 0.85 & 0.30 & 34.74 & \\
\hline & $3 R$ & 1.00 & 1.00 & 1.00 & 1.00 & 0.32 & 0.86 & 0.27 & 31.48 & \\
\hline & $4 \mathrm{~L}$ & 1.00 & 1.00 & 1.00 & 1.00 & 0.28 & 0.86 & 0.29 & 33.64 & \\
\hline & $5 \mathrm{~L}$ & 1.00 & 1.00 & 1.00 & 1.00 & 0.20 & 0.84 & 0.32 & 38.10 & \\
\hline & $6 \mathrm{R}$ & 1.00 & 1.00 & 1.00 & 1.00 & 0.17 & 0.83 & 0.33 & 39.81 & \\
\hline & $7 \mathrm{R}$ & 1.00 & 1.00 & 1.00 & 1.00 & 0.19 & 0.84 & 0.32 & 38.66 & \\
\hline & $8 \mathrm{R}$ & 1.00 & 1.00 & 1.00 & 1.00 & 0.39 & 0.88 & 0.24 & 27.79 & \\
\hline & 9L & 1.00 & 1.00 & 1.00 & 1.00 & 0.36 & 0.87 & 0.26 & 29.36 & \\
\hline \multirow[t]{6}{*}{ Middle } & $10 \mathrm{R}$ & 1.00 & 1.00 & 1.00 & 0.97 & 0.15 & 0.82 & 0.34 & 40.92 & \multirow[t]{6}{*}{39.51} \\
\hline & $11 \mathrm{~L}$ & 1.00 & 1.00 & 1.00 & 1.00 & 0.18 & 0.84 & 0.33 & 39.23 & \\
\hline & $12 \mathrm{R}$ & 1.00 & 1.00 & 1.00 & 1.00 & 0.19 & 0.84 & 0.32 & 38.66 & \\
\hline & $13 \mathrm{~L}$ & 1.00 & 1.00 & 1.00 & 0.94 & 0.17 & 0.82 & 0.33 & 39.76 & \\
\hline & $14 \mathrm{R}$ & 1.00 & 1.00 & 1.00 & 1.00 & 0.21 & 0.84 & 0.32 & 37.53 & \\
\hline & $15 \mathrm{R}$ & 1.00 & 1.00 & 1.00 & 0.97 & 0.15 & 0.82 & 0.34 & 40.92 & \\
\hline \multirow[t]{6}{*}{ Tail } & $16 \mathrm{~L}$ & 1.00 & 1.00 & 1.00 & 1.00 & 0.24 & 0.85 & 0.30 & 35.85 & \multirow[t]{6}{*}{62.46} \\
\hline & $17 \mathrm{R}$ & 1.00 & 1.00 & 1.00 & 1.00 & 0.21 & 0.84 & 0.32 & 37.53 & \\
\hline & $18 \mathrm{~L}$ & 1.00 & 1.00 & 0.64 & 0.51 & 0.07 & 0.64 & 0.35 & 53.83 & \\
\hline & $19 \mathrm{R}$ & 1.00 & 1.00 & 0.61 & 0.48 & 0.07 & 0.63 & 0.35 & 55.28 & \\
\hline & $20 \mathrm{~L}$ & 1.00 & 0.74 & 0.26 & 0.21 & 0.03 & 0.45 & 0.36 & 80.89 & \\
\hline & $21 \mathrm{~L}$ & 0.88 & 0.33 & 0.11 & 0.09 & 0.01 & 0.28 & 0.32 & 111.38 & \\
\hline Average & & 0.99 & 0.96 & 0.89 & 0.87 & 0.20 & 0.74 & 0.30 & 41.67 & 45.29 \\
\hline
\end{tabular}


Table.7 Equity-Values of Spatial Coefficient of Variation $\left(\mathrm{CV}_{\mathrm{R}}\right)$ of Ratio $\left(\mathrm{Q}_{\mathrm{D}} / \mathrm{Q}_{\mathrm{R}}\right) \mathrm{LMC}$

\begin{tabular}{|c|c|c|c|c|c|c|}
\hline \multirow{2}{*}{$\begin{array}{l}\text { Location of } \\
\text { Minor }\end{array}$} & \multirow[t]{2}{*}{ Outlet No. } & \multicolumn{5}{|c|}{ Ratio of $Q_{D} / Q_{R}$} \\
\hline & & NOV & DEC & JAN & FEB & MAR \\
\hline \multirow[t]{12}{*}{ Head } & $1 \mathrm{~L}$ & 1.00 & 1.00 & 1.00 & 1.00 & 0.32 \\
\hline & $2 \mathrm{R}$ & 1.00 & 1.00 & 1.00 & 1.00 & 0.26 \\
\hline & $3 R$ & 1.00 & 1.00 & 1.00 & 1.00 & 0.32 \\
\hline & $4 \mathrm{~L}$ & 1.00 & 1.00 & 1.00 & 1.00 & 0.28 \\
\hline & $5 \mathrm{~L}$ & 1.00 & 1.00 & 1.00 & 1.00 & 0.20 \\
\hline & $6 \mathrm{R}$ & 1.00 & 1.00 & 1.00 & 1.00 & 0.17 \\
\hline & $7 \mathrm{R}$ & 1.00 & 1.00 & 1.00 & 1.00 & 0.19 \\
\hline & $8 \mathrm{R}$ & 1.00 & 1.00 & 1.00 & 1.00 & 0.39 \\
\hline & 9L & 1.00 & 1.00 & 1.00 & 1.00 & 0.36 \\
\hline & Avg. & 1.00 & 1.00 & 1.00 & 1.00 & 0.28 \\
\hline & Std. Dev. & 0.00 & 0.00 & 0.00 & 0.00 & 0.08 \\
\hline & $\mathrm{CV}_{\mathrm{R}}(\%)$ & 0.00 & 0.00 & 0.00 & 0.00 & 28.17 \\
\hline \multirow[t]{9}{*}{ Middle } & $10 \mathrm{R}$ & 1.00 & 1.00 & 1.00 & 0.97 & 0.15 \\
\hline & $11 \mathrm{~L}$ & 1.00 & 1.00 & 1.00 & 1.00 & 0.18 \\
\hline & $12 \mathrm{R}$ & 1.00 & 1.00 & 1.00 & 1.00 & 0.19 \\
\hline & $13 \mathrm{~L}$ & 1.00 & 1.00 & 1.00 & 0.94 & 0.17 \\
\hline & $14 \mathrm{R}$ & 1.00 & 1.00 & 1.00 & 1.00 & 0.21 \\
\hline & $15 R$ & 1.00 & 1.00 & 1.00 & 0.97 & 0.15 \\
\hline & Avg. & 1.00 & 1.00 & 1.00 & 0.98 & 0.18 \\
\hline & Std. Dev. & 0.00 & 0.00 & 0.00 & 0.02 & 0.02 \\
\hline & $\mathrm{CV}_{\mathrm{R}}(\%)$ & 0.00 & 0.00 & 0.00 & 2.50 & 13.40 \\
\hline \multirow[t]{9}{*}{ Tail } & $16 \mathrm{~L}$ & 1.00 & 1.00 & 1.00 & 1.00 & 0.24 \\
\hline & $17 \mathrm{R}$ & 1.00 & 1.00 & 1.00 & 1.00 & 0.21 \\
\hline & $18 \mathrm{~L}$ & 1.00 & 1.00 & 0.64 & 0.51 & 0.07 \\
\hline & $19 \mathrm{R}$ & 1.00 & 1.00 & 0.61 & 0.48 & 0.07 \\
\hline & $20 \mathrm{~L}$ & 1.00 & 0.74 & 0.26 & 0.21 & 0.03 \\
\hline & $21 \mathrm{~L}$ & 0.88 & 0.33 & 0.11 & 0.09 & 0.01 \\
\hline & Avg. & 0.98 & 0.85 & 0.60 & 0.55 & 0.11 \\
\hline & Std. Dev. & 0.05 & 0.27 & 0.37 & 0.38 & 0.10 \\
\hline & $\mathrm{CV}_{\mathrm{R}}(\%)$ & 5.00 & 32.29 & 61.00 & 70.10 & 91.70 \\
\hline
\end{tabular}

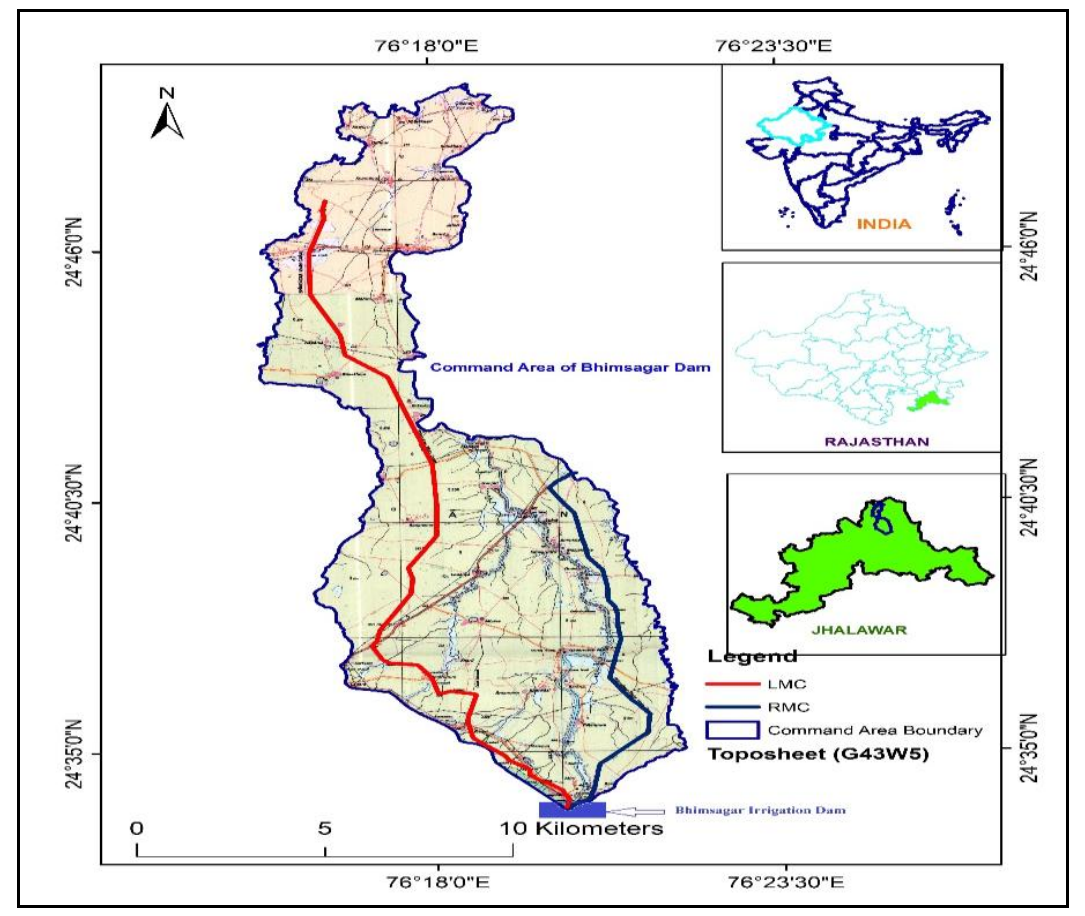

Figure.1 Location of the study area 


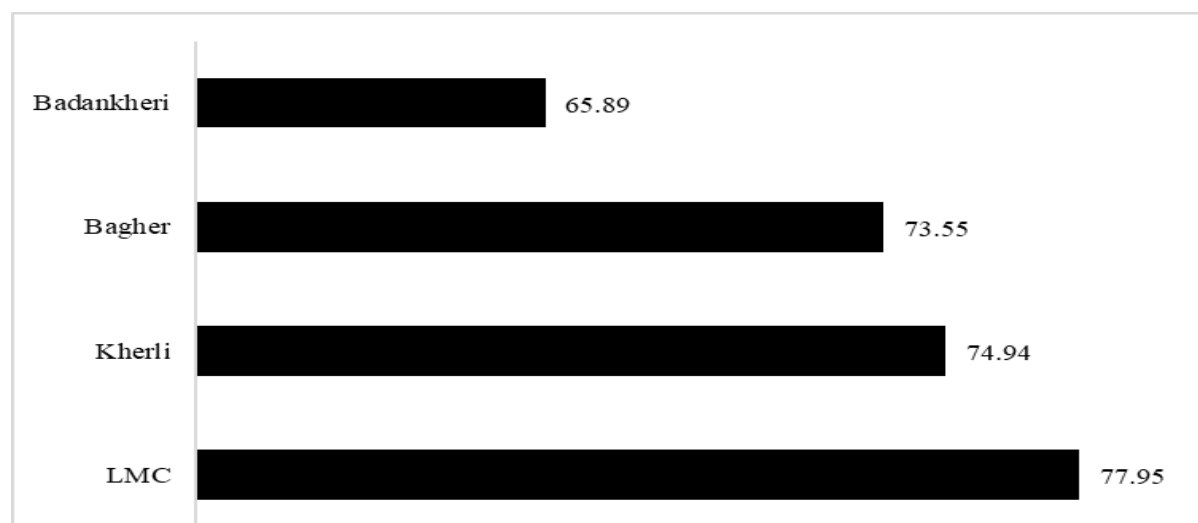

Figure.2 Water conveyance efficiency $\left(\mathrm{E}_{\mathrm{C}}\right)$ for $\mathrm{LMC}$ and its selected minors

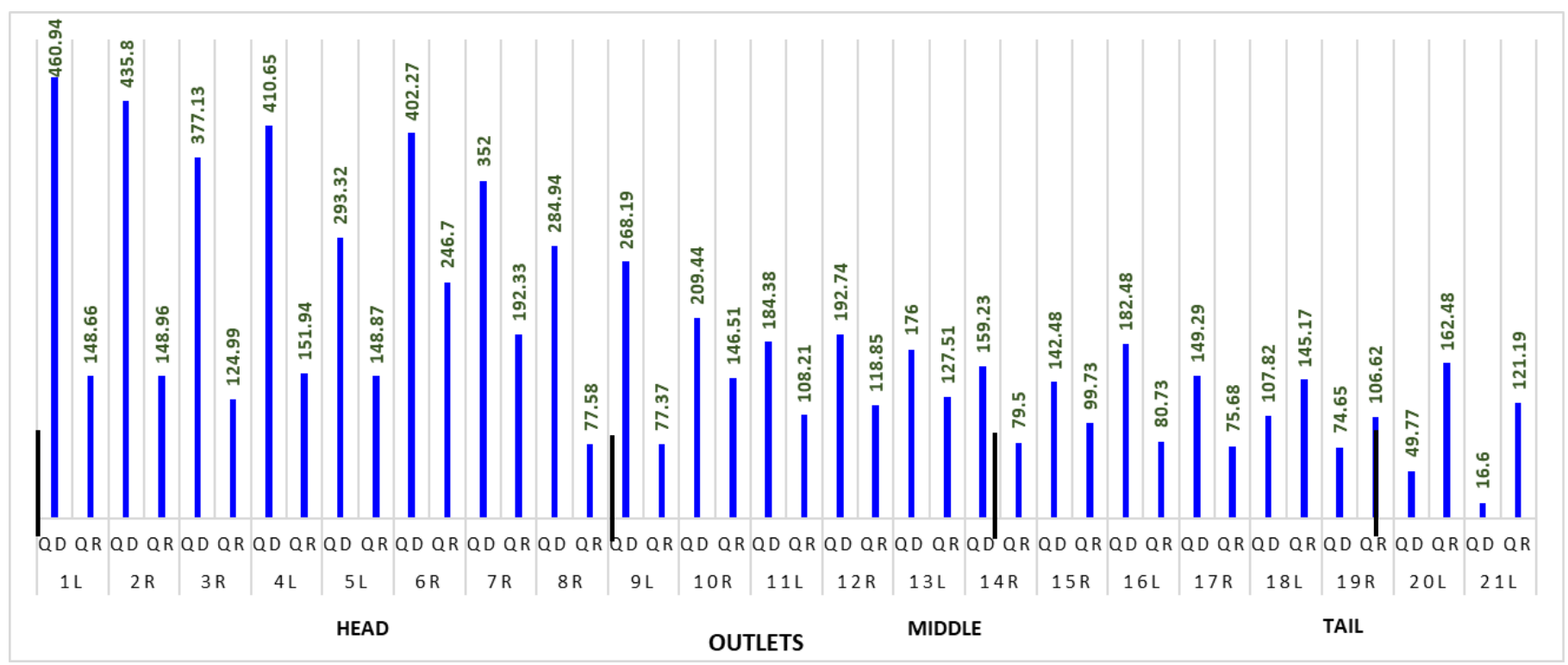

Figure.3 The Values of Water Delivered $\left(Q_{D}\right)$ and Required Flow Rate $\left(Q_{R}\right)$ in $10^{3} \mathrm{~m}^{3}$ at Selected Outlets of LMC

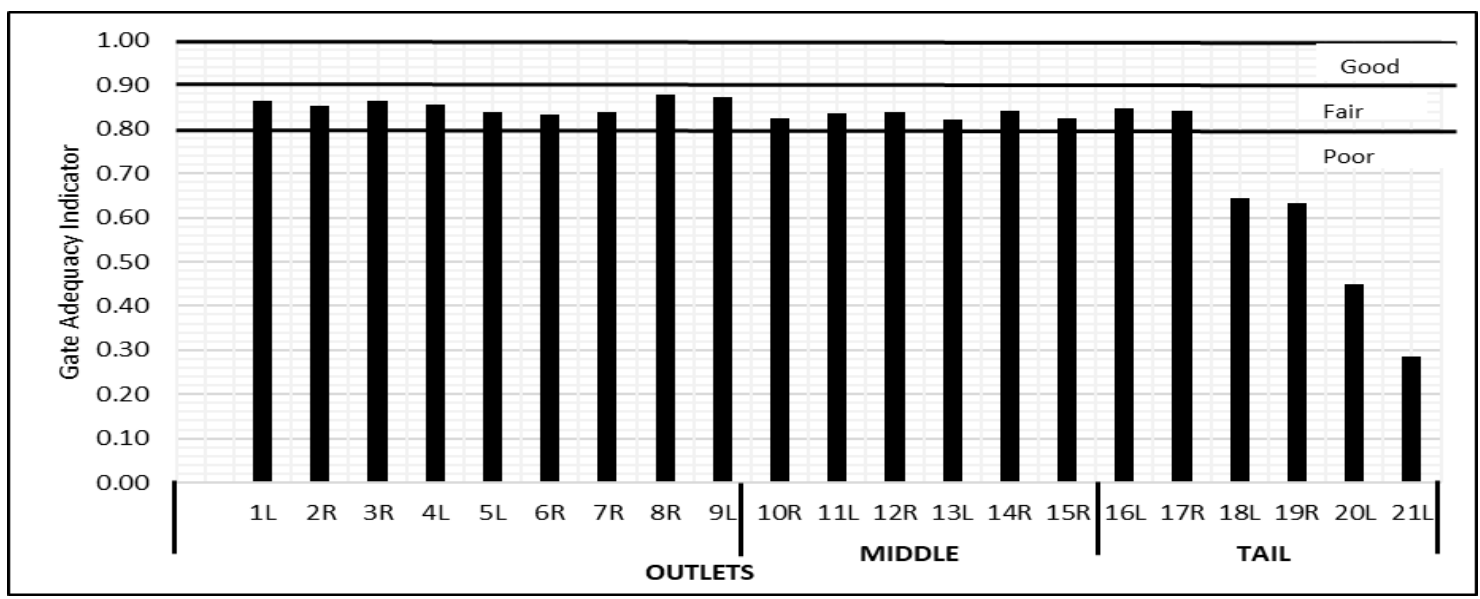

Figure.4 Temporal Average Values of Gates Adequacy Indicator (GAI) at Selected Outlets of LMC 


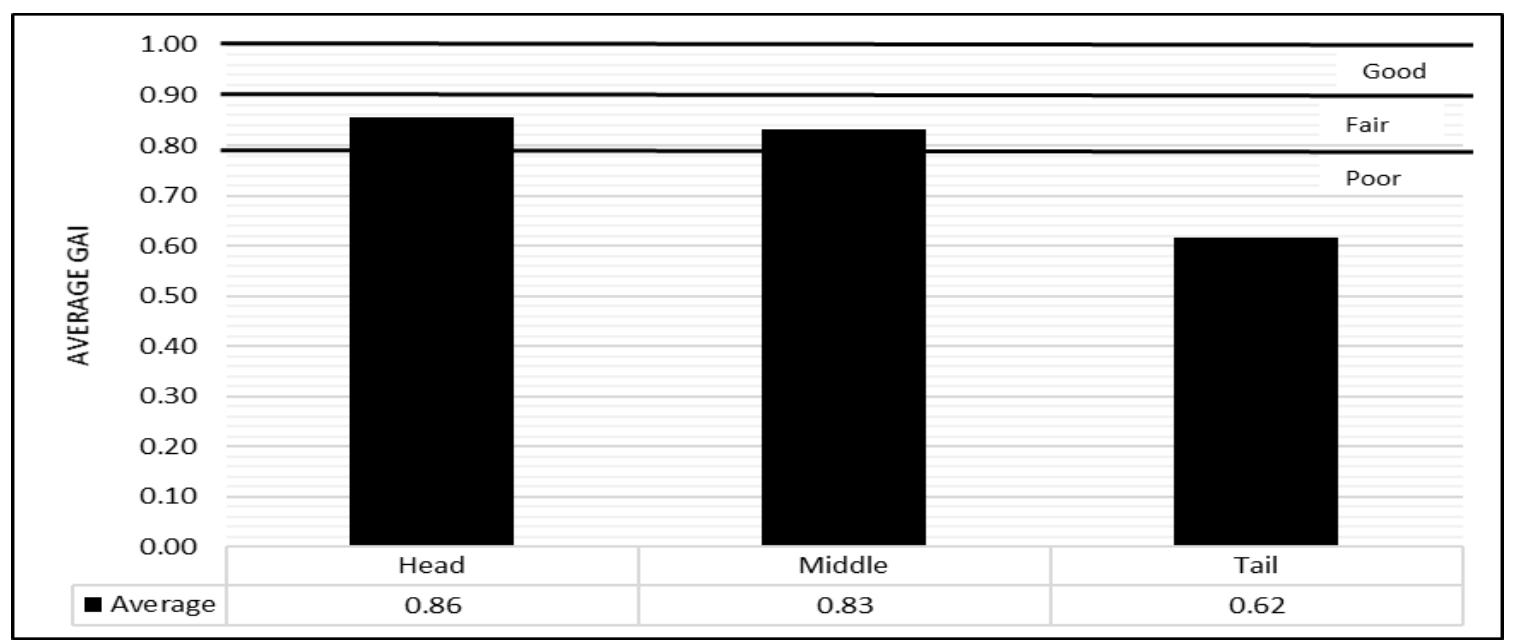

Figure.5 Spatial Average Value of Gates Adequacy Indicator at Head, Middle and Tail Sections of LMC

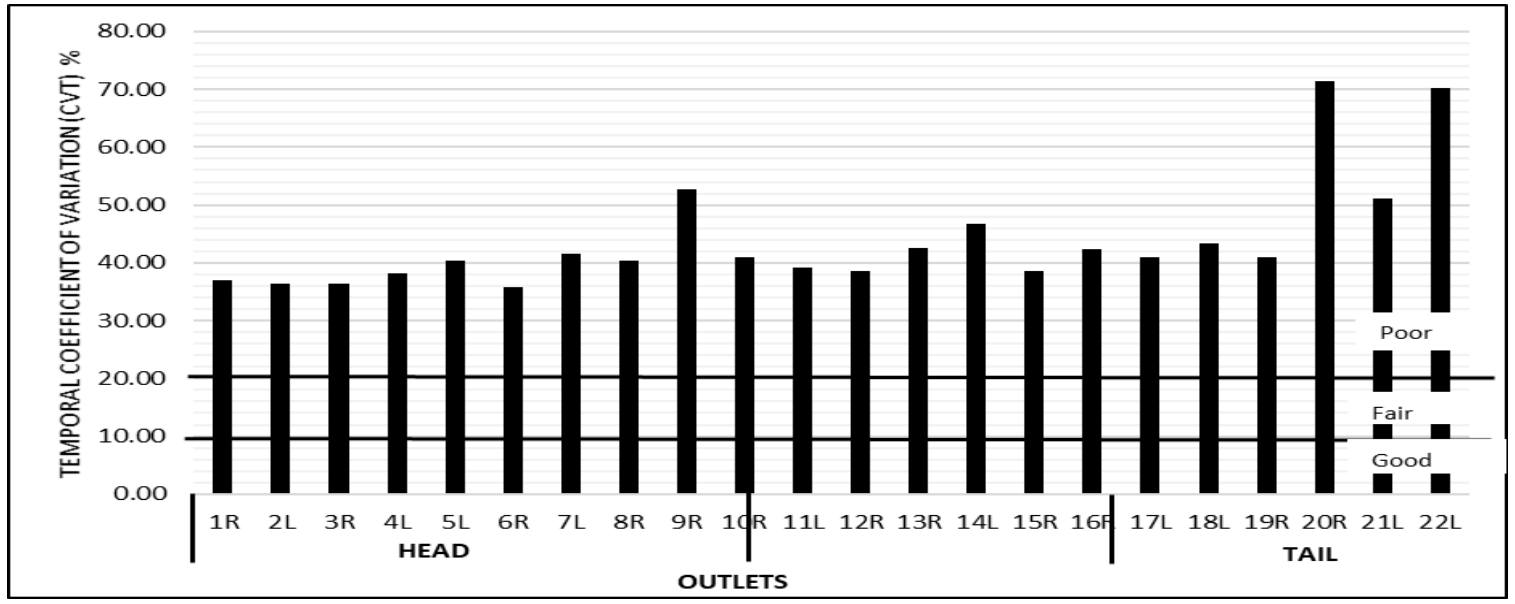

Figure.6 Dependability - Values of Temporal Coefficient of Variation $\left(\mathrm{CV}_{\mathrm{T}}\right)$ of the ratio $\left(\mathrm{Q}_{\mathrm{D}} / \mathrm{Q}_{\mathrm{R}}\right)$ for Selected Outlets of LMC

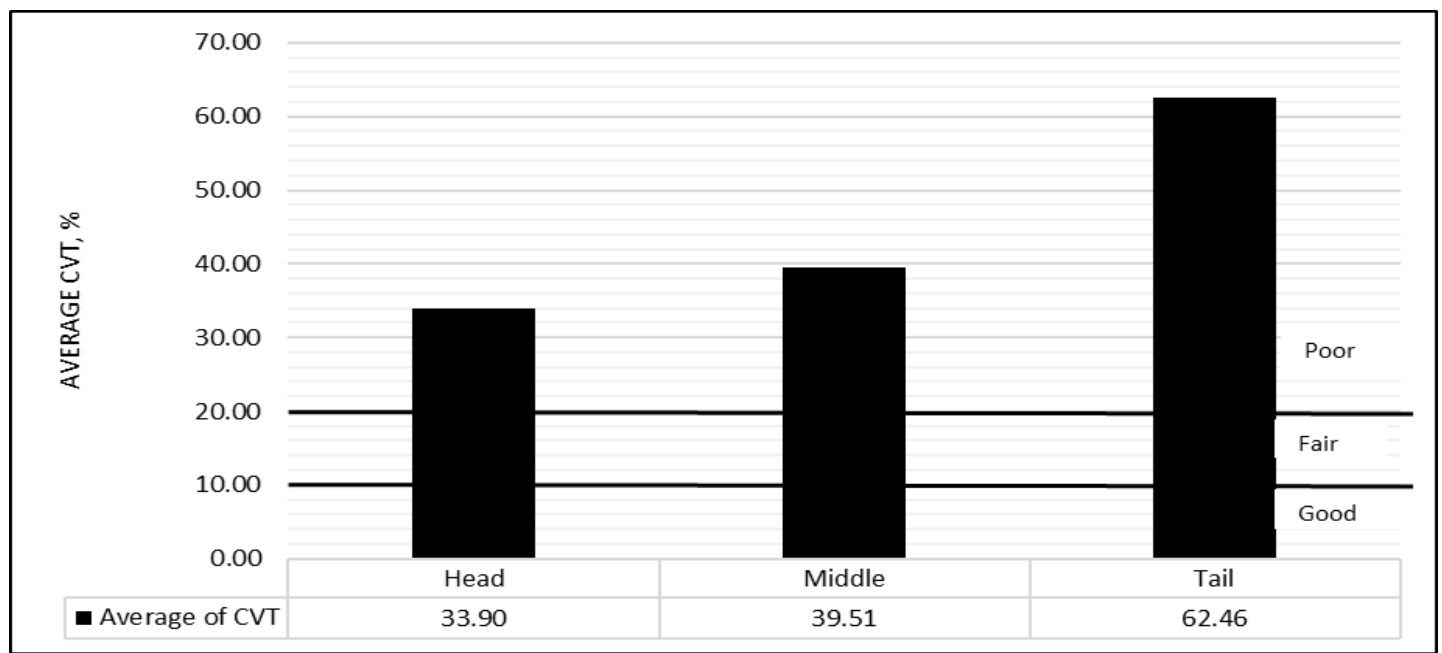

Figure.7 Spatial Average of $\mathrm{CV}_{\mathrm{T}}$ values at Head, Mid and Tail Sections of LMC 


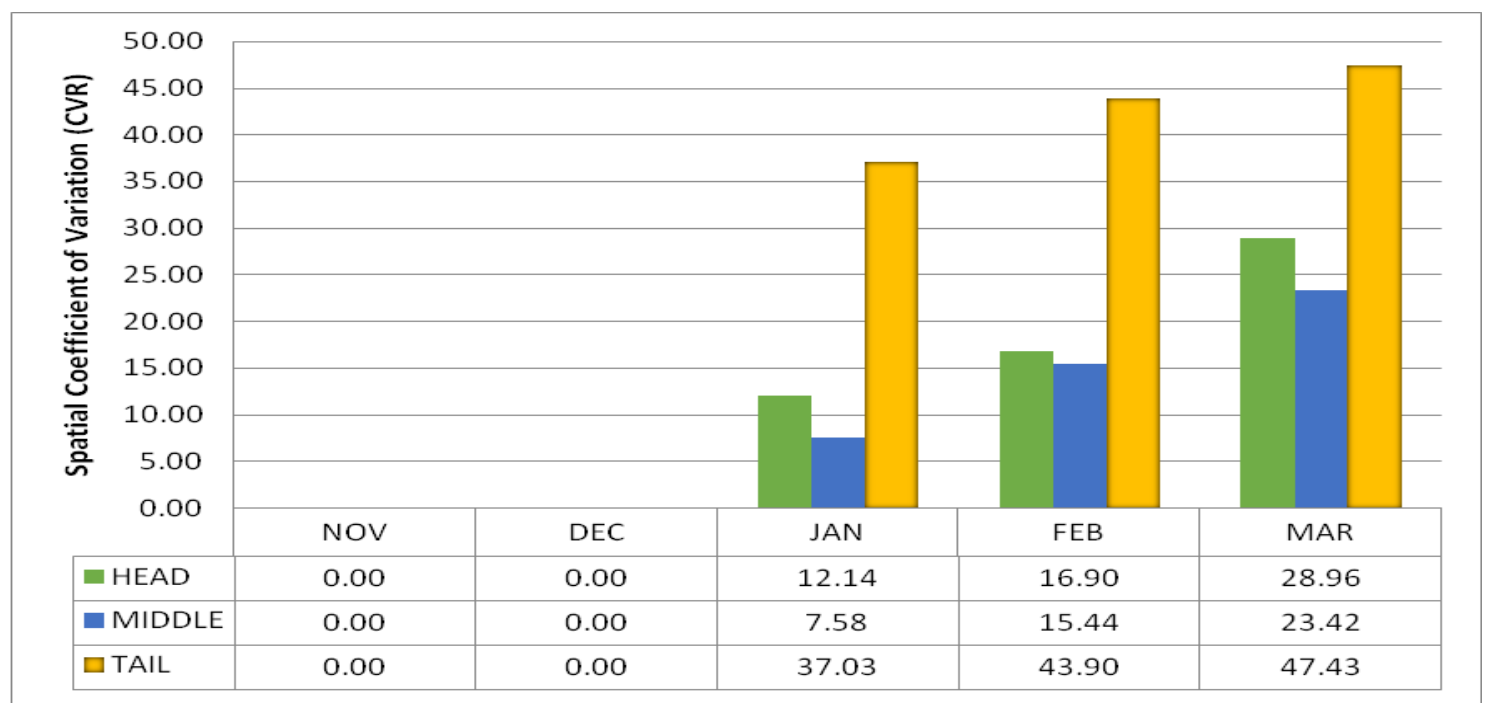

Figure.8 Equity - Values of Spatial Coefficient of Variation $\left(\mathrm{CV}_{\mathrm{R}}, \%\right)$ from November to March months for LMC

Therefore, there is a necessity to make certain management and restoration of damage canal in order to improve performance. In order to pursue to improving conveyance efficiency of the canal, it is necessary to remove vegetation, weed infestation and deposited silt.

The land need to be levelled with machineries so that the application efficiency can be improved. Water users should be informed and educated about efficient water use.

\section{Acknowledgement}

Author acknowledges Irrigation Department, Govt. of Rajasthan; Agriculture department, Khanpur tehsil, Jhalawar for providing secondary data necessary for this study. India Meteorological Department (IMD), Pune (MS) for providing rainfall data. All canal staffs of Bhimsagar Medium Irrigation Project, Jhalawar, Dr. Chandrakant Arya, Asst. Prof., COHF, Jhalawar for providing necessary facility at lab and instruments. KrishiVigyan Kendra (KVK), Jhalawar for providing pleasant stay during this study.

\section{References}

Allen RG, Jensen ME, Wright JL, Burman RD. 1989. Operational estimates of reference evapotranspiration. Agronomy Journal. 81(4):650-62.

American Society of Civil Engineers/ASCE. 1978. Describing Irrigation Efficiency and Uniformity. The On-farm Irrigation Committee of the Irrigation and Drainage Division of the ASCE. Proceedings of the ASCE 104, IR 1:3541.

Bos MG, Murray-Rust DH, Merrey DJ, Johnson HG, Snellen WB. 1993. Methodologies for assessing performance of irrigation and drainage management. Irrigation and Drainage Systems.7(4):231-61.

Bos MG, Burton MA, Molden DJ. 2005.Irrigation And Drainage Performance Assessment: Practical Guidelines. viii. CABI: Wallingford, UK; 158.

Central Water Commission (CWC). 2014. Guidelines for compting the water use efficiency (WUE) of the irrigation projects. Performance Overview \& 
Management

Improvement

Organization, CWC, Ministry of Water Resource. pp.1-21

Clemmens AJ, Bos MG. 1990. Statistical methods for irrigation system water delivery performance evaluation. Irrigation and drainage Systems. 4(4):345-65.

Clemmens A, Molden D. 2007. Water use and productivity of irrigation systems. Irrigation Science.25: 247-261.

Dhole VV, KothariMahesh. 2011. Performance evaluation of water delivery system for command area of Som-Kagdar Irrigation Project, Rajasthan. International Journal of Agricultural Engineering.4(1): 1-7.

FAO, 1998. Crop evapotranspiration: guidelines for computing crop water requirements. Ed. R.G. Allen, L.S. Pereira, D. Raes and M. Smith. FAO Irrigation and Drainage Paper 56. Rome, FAO. pp.123

Fan Y, Gao Z, Wang S, Chen H, Liu J. 2018. Evaluation of the water allocation and delivery performance of Jiamakou Irrigation Scheme, Shanxi, China. Water. 10(5):654.

Gorantiwar SD,Smout IK. 2005. Performance assessment of irrigation water management of heterogeneous irrigation schemes:A framework for evaluation. Irrigation and Drainage Systems. 19: 136.

Hamdy A. 2007. Water use efficiency in irrigated agriculture: an analytical review. Water use efficiency and water productivity: WASAMED project, pp.919.

Julaia CS. 2009. Performance assessment of water distribution system inlarge scale irrigation systems: a case study of Chokwe Irrigation System in Mozambique. UNESCO-IHE Institute for Water Education: Delft, the Netherlands; 42-55 pp.
Kazbekov J, Manthrithilake H, Qureshi A, Jumaboev K, Abdullaev I. 2009. Evaluating planning and delivery performance of water user associations (WUA) in Osh Province, Kyrgyzstan. Agricultural Water Management 2728:9

Korkmaz N, Avci MU, Unal HB, Asik S, Gunduz M. 2009. Evaluation of the water delivery performance of the Menemen Left Bank irrigation system using variables measured on-site. Journal of Irrigation and Drainage Engineering. 35(5):633-42.

Marikar F, Wilkin- Wells J, Smolnik S, Sampath RK. 1992. Irrigation system performance and its impact on crop productivity in Sri Lanka. International Journal of Water Resources Development. 8(4):226-34.

Molden DJ, Gates TK. 1990. Performance measures for evaluation of irrigationwater-delivery systems. Journal of Irrigation and Drainage Engineering. 116(6):804-23.

Murray-Rust, DH, Snellen WB. 1993. Irrigation system performance assessment and diagnosis. International Water Management Institute, Colombo, Sri Lanka.

Pareira L. 2003. Proceeding of the internationalworkshop on participatory management of irrigationsystems, water utilization techniques hydrology, Asession of the 3rd world water forum, Theme: Agriculture,Food \& Water, March 2003.

Rajput J, Kothari Mahesh, Bhakar SR 2017. Performance Evaluation of Water Delivery System for Command Area of Left Main Canal of Bhimsagar Irrigation Project, Rajasthan. Journal of Agricultural Engineering.54(3): 57-66.

Rao PS. 1993. Review of selected literature on indicators of irrigation performance, International Water Management Institute, Colombo, Sri Lanka, 75. 
Sharma U, Kothari Mahesh, Dashora Y. 2018. Performance Assessment of Water Delivery and Distribution in SomKamlaAmba Irrigation Scheme. Irrigation and Drainage.68(2): 227233.

Small LE, Svendsen M. 1990. A framework for assessing irrigation performance. Irrigation and Drainage System.4: 283312.

Tarate SB,Awari HW. 2018. Performance Evaluation of Water Delivery System for Command Area of Branch Canal 70 of Jayakwadi Irrigation Project.Indian Journal of Ecology.45(4): 750-755.
Unal HB, Asik S, Avci MU, Yasar S, Akkuzu ER. 2004. Performance of water delivery system at tertiary canal level: a case study of the Menemen Left Bank Irrigation System, Gediz Basin, Turkey. Agricultural Water Management. 65(3):155-71.

Vandersypen K, Bengaly K, Keita AC, Sidibe S, Raes D, Jamin JY. 2006. Irrigation performance at tertiary level in the rice schemes of the Office du Niger (Mali): adequate water delivery through oversupply. Agricultural Water Management. 83(1-2):144-52.

\section{How to cite this article:}

Patil. P. R., Mahesh Kothari, P. K. Singh and Bhakar. S. R. 2020. Performance Assessment of Left Main Canal of Bhimsagar Medium Irrigation Project Using Water Delivery and Technical Indicators. Int.J.Curr.Microbiol.App.Sci. 9(06): 204-220.

doi: https://doi.org/10.20546/ijcmas.2020.906.027 